\title{
GOVERNMENT AND FOREIGN ENTREPRENEURS IN THE SOVIET ECONOMY OF THE 1920s - 1940s: RELATIONS, CONTRADICTIONS AND RESULTS
}

\author{
Taisiya V. Yudina \\ Volgograd State University, Volgograd, Russian Federation
}

\begin{abstract}
Introduction. The article reveals motives of attracting foreign entrepreneurs to Soviet economy, difficulties with hiring local labor force in concessions, contradictions and solutions between Soviet organizations and concessioners. Relations between foreign entrepreneurs and Soviet government agencies as well as Soviet engineers and workers were regulated by the law. Methods and materials. The author uses the comparative historical method in the work, which makes it possible to compare the number of foreign and domestic labor in concession enterprises, to show the need of attracting foreign specialists to concession and state enterprises, to reveal the cooperation of foreign entrepreneurs with the Soviet state. Sources from The State Archive of the Russian Federation, The Russian State Archive of Economics and The Russian State Archive of Social and Political History were identified for the study. Regulatory acts of state significance (decrees, concession agreements) reflecting the policy of the state in relation to the economic activity of private capitalists; records management documentation (circulars, official correspondence, reporting documentation) covering the real state of affairs at concession enterprises allow to show the peculiarities of relations between Soviet state institutions and foreign entrepreneurs. Analysis. Sometimes concessioners did not meet the governmental requirements in labor force attraction, which caused mutual claims. The author also analyses hiring foreign professionals in Soviet state enterprises because of their important contribution to the Soviet economy recovery and development. Foreign professionals were involved in the production process organization and local labor force education at Kuznetskiy coalfield minery, Stalingrad tractor factory and other state enterprises. Concessions were equipped with brand-new techniques and technologies and were also involved in the local labor force education. Results. The article analyzes the reasons of early cancellation of contracts by foreign professionals and workers and their mass departure from the USSR in the 1930s - 1940s. For example, prosecution and custody for industrial accidents were among of such reasons. Despite this, new foreign engineers were forbidden to enter Sakhalin island by Soviet authorities. The article focuses on the correlation between the deterioration of the international situation from the middle 1930s and existence of Japanese concessions in the USSR until the middle 1940s. The author pays a lot of attention to investigate the issue of obeying to the Soviet labor law by concessioners using unpublished archived documents.

Key words: concessions, concessioners, labor force, Soviet economy, concession practice, relations, contradictions.
\end{abstract}

Citation. Yudina T.V. Government and Foreign Entrepreneurs in the Soviet Economy of the 1920s - 1940s: Relations, Contradictions and Results. Vestnik Volgogradskogo gosudarstvennogo universiteta. Seriya 4. Istoriya. Regionovedenie. Mezhdunarodnye otnosheniya [Science Journal of Volgograd State University. History. Area Studies. International Relations], 2019, vol. 24, no. 5, pp. 100-110. (in Russian). DOI: https://doi.org/10.15688/jvolsu4.2019.5.7

УДК 94(47+57):338

Дата поступления статьи: 22.04.2019

ББК 63.3(2)6-2

Дата принятия статьи: 21.06.2019

\section{ВЛАСТЬ И ИНОСТРАННЫЕ ПРЕДПРИНИМАТЕЛИ \\ В СОВЕТСКОЙ ЭКОНОМИКЕ 1920-1940-х гГ.: ВЗАИМООТНОШЕНИЯ, ПРОТИВОРЕЧИЯ, РЕЗУЛЬТАТЫ}

\author{
Таисия Васильевна Юдина
}

Волгоградский государственный университет, г. Волгоград, Российская Федерация 
Аннотация. В статье освещены причины привлечения иностранных предпринимателей в советскую экономику, трудностей найма отечественной рабочей силы на концессионные предприятия; показаны противоречия между советскими организациями и концессионерами, их устранение. Для исследования были выявлены источники из фондов Государственного архива Российской Федерации, Российского государственного архива экономики и Российского государственного архива социально-политической истории. Взаимоотношения иностранных предпринимателей с государственными учреждениями, советским инженернотехническим персоналом и рабочими определялись законодательными документами. Но концессионеры не всегда соблюдали требования органов власти в сфере привлечения рабочей силы, что давало повод для взаимных претензий. Для более полного понимания вклада не только иностранных предпринимателей, но и специалистов в восстановление и развитие советской экономики проанализирован вопрос трудоустройства последних и на государственные предприятия СССР. На рудниках Кузнецкого каменноугольного бассейна, Сталинградского тракторного завода и других государственных предприятиях страны иностранных специалистов использовали в организации производственной деятельности, организовывали передачу их опыта, знаний советским рабочим и инженерам; на концессионных предприятиях применялись новейшая техника, передовые технологические процессы, проходило обучение советских рабочих. В статье исследованы причины досрочного завершения контрактов и массового отъезда из СССР на родину иностранных служащих и квалифицированных рабочих в 1930-1940-е годы. Привлечение к уголовной ответственности и тюремное заключение иностранных специалистов за несчастные случаи на концессионных предприятиях вызывало обеспокоенность у квалифицированных иностранных рабочих и способствовало их переезду на родину. В то же время въезд, например, на о. Сахалин новых японских инженеров не разрешался советскими органами власти. Акцентировано внимание на взаимосвязи ухудшения международной обстановки с середины 1930-х гг. и функционирования концессионных (японских) предприятий в СССР до середины 1940-х годов. Большое внимание уделено вопросам соблюдения советских трудовых норм концессионерами на основе ранее неопубликованных архивных документов.

Ключевые слова: концессионные предприятия, концессионеры, рабочая сила, советская экономика, концессионная практика, взаимоотношения, противоречия.

Цитирование. Юдина Т. В. Власть и иностранные предприниматели в советской экономике 19201940-х гг:: взаимоотношения, противоречия, результаты // Вестник Волгоградского государственного университета. Серия 4, История. Регионоведение. Международные отношения. - 2019. - Т. 24, № 5. - С. 100110. - DOI: https://doi.org/10.15688/jvolsu4.2019.5.7

Введение. В современной историографии при возросшем интересе к социальной истории и истории повседневности значительно расширилось и изучение роли иностранного капитала в советской экономике, деятельности иностранных инвесторов, трудовых отношений. Вопрос привлечения иностранных трудовых ресурсов, в том числе и изучение исторического опыта России в данной области, имеет особую актуальность в современных условиях страны при сложной реализации программы импортозамещения. Также непростые отношения, сложившиеся в современном российском обществе между различными движениями, партиями, особенно в предвыборных условиях, заставляют обратиться к историческим урокам. И не только к анализу взаимоотношений между партиями и народом, общественными организациями и гражданами, но и малоисследованной темы - между государством и иностранными предпринимателями. Изучение исторического опыта поведения органов власти в отношении концессионеров требует и развитие рыночных отношений в Российской Федерации.

В статье обобщены причины активного привлечения иностранного капитала в форме концессий в советскую экономику в 1920-е гг.; определены требования советских органов власти и профсоюзов по трудовым отношениям к концессионерам, заключившим договоры с правительством СССР в указанный период; выявлены причины трудностей найма отечественной рабочей силы на концессионные предприятия в 1920-1940-е гг. и противоречия во взаимоотношениях органов власти и концессионеров.

Методы и материалы. В работе широко применяется сравнительно-исторический метод, позволяющий сравнить численность иностранной и отечественной рабочей силы на концессионных предприятиях, показать необходимость привлечения иностранных специалистов на концессионные и государствен- 


\section{ВЛАСТЬ И ОБЩЕСТВО}

ные предприятия, раскрыть сотрудничество зарубежных предпринимателей с Советским государством.

Для исследования взаимоотношений власти и концессионеров в 1920-1940-е гг. были выявлены источники из фондов Государственного архива Российской Федерации, Российского государственного архива экономики и Российского государственного архива социально-политической истории. Нормативно-правовые акты государственного значения (декреты, концессионные договоры), отражавшие курс политики государства в отношении частнокапиталистической хозяйственной деятельности; делопроизводственная документация (циркуляры, служебная переписка, отчетная документация), освещавшая реальное положение дел на концессионных предприятиях, позволили показать особенности взаимоотношений советских государственных учреждений с иностранными предпринимателями.

Обсуждение. Вопросы взаимодействия иностранных предпринимателей с советскими органами власти по трудовым и социальным отношениям, соблюдения ими советских трудовых норм на концессионных предприятиях отечественными исследователями стали освещаться одновременно с привлечением иностранного капитала в советскую экономику. В связи с массовой ликвидацией концессионных предприятий, исчерпанностью концессионной практики в конце 1920-х гг. иссякает интерес к указанной теме. С возросшим интересом к периоду нэпа, составной частью которого являлась концессионная политика, с конца 1980-х - начала 1990-х гг. рядом отечественных авторов предпринимаются попытки расширения тематики исследований, углубленного изучения проблемы трудовых и социальных отношений на концессионных предприятиях в 1920-е годы.

Автор статьи продолжает серию исследований, посвященных опыту концессионеров по привлечению рабочей силы на свои предприятия, расширяя хронологические рамки до середины 1940-х гг., ликвидации последних концессий в СССР, на основе привлечения выявленных архивных документов. При этом впервые в исследовательской литературе обращено внимание на отсутствие дефицита отечественной квалифицированной рабочей силы и ее преимущественный состав на японской дальневосточной концессии в годы Великой Отечественной войны, что свидетельствовало о значительных изменениях в рабочем социуме СССР.

Анализ. В 1920-е гг. партия большевиков, советские органы власти пытались через известных и успешных иностранных предпринимателей решить сложнейшую задачу восстановления разрушенного национального хозяйства после изнурительных военных лет 1914-1920 гг. и политики «военно-коммунистического» хозяйствования 1917-1920 годов. Также власть стремилась обеспечить выход страны из политической и экономической изоляции.

Осуществляя модернизаторский рывок, советские органы власти в 1920-е гг. разработали экономические меры и приняли ряд нормативных документов: Кодекс законов о труде, налоговое законодательство, законодательство в сфере привлечения иностранных предпринимателей, рабочей силы. 23 ноября 1920 г. был опубликован Декрет СНК РСФСР «Общие экономические и юридические условия концессий», 29 марта 1921 г. - «Основные принципы концессионных договоров».

В начале 1920-х гг. первыми государствами, начавшими экономическое сотрудничество с советской властью посредством концессионных предприятий, стали США, Англия и Германия.

Основными целями заключения концессионных договоров со стороны советского правительства являлись: получение иностранного капитала, например, «“на достройку дороги и привлечение иностранного капитала для развития лесной промышленности Союза" (речь идет о германской концессии "Мологолес" “для достройки Мга-Рыбинской железной дороги и эксплуатацию лесных массивов”)» [10, л. 38]. При заключении договоров, а также при функционировании концессионных предприятий не всегда удавалось избежать ошибок, недоразумений. Так, после подписанного советским правительством концессионного договора с «Мологолесом» в сентябре 1923 г., спустя почти 2 года, в июле 1925 г. начальниками экономического управления Благонравовым и 1-го отделения ОГПУ Молочниковым было проведено обследование 
указанной концессии, в ходе которого были выявлены «недобросовестные действия концессионера при заключении договора». Суть их сводилась к следующему: в районе концессии оказались «ценные, почти единственные в Союзе, участки авиолеса» и лесные массивы Максатихинского завода государственного треста «Верхне-Волго-лес» [10, л. 38], вследствие чего завод остался без сырья. Количество отпущенного леса концессионеру «при перечете лесосек показано на 50 \% ниже действительности» $[10$, л. 39].

Также острой критике со стороны ОГПУ подвергся социальный состав советских служащих «Мологолеса», представленный бывшими лесопромышленниками, помещиками, кулаками, полицейскими и «всеми теми, кто не находит себе места в наших государственных учреждениях, как по причине своего дореволюционного прошлого, так и вследствие своих преступных действий на советской службе». Служащих обвинили в том, что они великолепно знают все местные условия и используют «все слабости советского аппарата в пользу концессионера» $[10$, л. 38]. По данным ОГПУ за 1924 г. на Крупповской сельскохозяйственной концессии руководителями являлись бывшие офицеры германского штаба и армии, которые вели «разведку в пользу Германии. Тоже самое наблюдается в концессии Вольфа (русско-германское общество в Ростове-на-Дону)». В Вологодскую лесную концессию оформлялись сотрудники германского Генерального Консульства «не без разведывательных соображений» [25, л. 43].

Такие противоречия на начальном этапе активного привлечения иностранного капитала в национальную экономику в форме концессионной помощи объясняются незаинтересованностью советских организаций в стабильной, эффективной работе предприятий с иностранным инвестором. Однако в целом советское руководство осознавало необходимость участия концессионеров в восстановлении экономики и индустриализации страны и продолжало привлекать капитал не только германский, американский, английский, но и датский, шведский, польский, норвежский, финский, итальянский, японский и т. д. Концессионные договоры заключались до конца 1920-х гг., времени свертывания новой экономической политики в СССР. Концессионные предприятия создавались в горнодобывающей, обрабатывающей и других отраслях советской промышленности. Распределенные неравномерно, они функционировали в разных регионах страны, в соответствии с решением советского правительства - Совета народных комиссаров (СНК). С помощью концессионных предприятий были восстановлены горная промышленность, отдельные предприятия металлообрабатывающей промышленности и др.

Трудовые отношения, возникавшие в процессе производственной деятельности на концессионных предприятиях, регулировались советским законодательством - Кодексом законов о труде, необходимыми положениями концессионных договоров (например, в концессионном договоре «Американской алюминиевой компании» от 10 июля 1926 г. не прописанным трудовым отношениям был посвящен $\S 21$ : «По всем вопросам, специально в настоящем договоре не упомянутым, Компания подчиняется действию общих законов СССР» $[8$, л. 20]) и правовыми актами - коллективными договорами. Государственный надзор за соблюдением трудового законодательства на концессионных предприятиях осуществляли Народные комиссариаты труда и иностранных дел, профсоюзы СССР, контроль и наблюдение за концессиями, в первую очередь немецкими, - ОГПУ. Следует отметить, что заместитель председателя ОГПУ Г. Ягода указывал на необходимость наблюдения и за местными хозяйственными органами, которые не только выдают справки иностранцам о положении нашего хозяйства, а «даже сообщают сведения без контроля и разрешения центра, непосредственно выходящим за границей изданиям, для опубликования...» [25, л. 45].

Регламентация социально-трудовых отношений позволяла предупреждать нарушения трудового законодательства. В первую очередь концессионерам вменялось в обязанность знакомить принимаемых на работу советских граждан с Кодексом законов о труде, коллективными договорами и соблюдать их, выполнять их основные положения.

Однако в начальный период проведения советской концессионной политики некоторые иностранные соискатели концессий выдвигали неприемлемые с точки зрения советского 
трудового законодательства требования. Например, в отношении условий труда рабочих, предприниматели требовали, чтобы:

1) не существовало обязательного условия приема на работу только членов профсоюза;

2) наем рабочих не производился на основе коллективных договоров или соглашений с соответствующими профсоюзами;

3) конфликты между ними и рабочими решались исключительно в арбитражном суде.

Несмотря на предъявляемые требования концессионерами, на практике наем рабочей силы должен был производиться ими через органы Народного комиссариата труда в соответствии со статьей 23 Кодекса законов о труде. Самостоятельно нанимать рабочих концессионеры могли в порядке, предусмотренном коллективным договором, лишь при невозможности предоставления ему советских квалифицированных рабочих. Применение наемного труда на концессионных предприятиях было узаконено Постановлением СНК СССР «Основные положения, определяющие порядок осуществления концессионного дела в целом» только 16 августа 1928 г. VI разделом «О применении наемного труда на концессионных предприятиях». Но до 1928 г., начиная с 1921 г. - времени создания первых концессионных предприятий, порядок найма на концессии полностью соответствовал положениям Постановления. Концессионер получал право нанимать рабочих для своего предприятия на территории советской России при соблюдении Кодекса законов о труде или особого договора, обеспечивавшего охрану труда, медицинского обеспечения и быта рабочих [27, с. 84-85]. К тому же в одном из первых законодательных документов - Декрете СНК РСФСР «Основные принципы концессионных договоров» от 29 марта 1921 г. четко излагалось требование концессионерам: «улучшать положение занятых в концессионных предприятиях (по сравнению с другими рабочими, занятыми в аналогичных предприятиях той же местности) до средней заграничной нормы» [14, с. 36].

Следует отметить, что на всем протяжении концессионной практики проблема найма советских квалифицированных рабочих для концессионеров являлась острой из-за их дефицита. Переписка начальника управления Народного комиссариата продовольствия Троцкого с управляющим делами концессионного комитета ВСНХ Зубаревым в 1924 г. по вопросу «устройства в Донской области молочно-консервного хозяйства Крупповской сельскохозяйственной концессией "Маныч" свидетельствует: “Желательно, чтобы концессионным договором была предусмотрена постепенная замена иностранного рабочего и служебного персонала на фабрике персоналом из граждан СССР...”» [3, л. 10]. В первом законодательном документе, посвященном вопросам привлечения иностранного капитала в советскую Россию, Декрете СНК РСФСР «Общие экономические и юридические условия концессий» от 23 ноября 1920 г. в п. 5 проблема найма отечественных кадров обозначалась следующим образом: «Концессионеру будет предоставляться право найма рабочих и служащих для своих предприятий на территории РСФСР с соблюдением Кодекса законов о труде или специального договора, гарантирующего соблюдение по отношению к ним определенных условий труда, ограждающих их жизнь и здоровье» [6]. Недостаток квалифицированной советской рабочей силы объяснялся в начале 1920-х гг., по мнению исследователей С.П. Постникова и М.А. Фельдмана, снижением реальной зарплаты промышленных рабочих в четыре раза в 19191920 гг., что фактически поставило на грань вымирания тот класс, который рассматривался как главная сила обновления страны [16, с. 6263]. Невысокая квалификация рабочих промышленности СССР, неблагоприятные условия труда диктовались инерцией социальной политики государства [16, с. 44-45, 50]. Как следствие, недовольство рабочих условиями жизни и нежелание повышать свою общеобразовательную и профессиональную подготовку наблюдалось на протяжении многих лет.

Японские рыбопромышленники, осведомленные о дефиците рабочей силы в советской рыболовной отрасли промышленности, в 1923 г. обращались в Народный комиссариат иностранных дел СССР с просьбой допустить японских рабочих «на промыслы без виз и беспошлинном ввозе промыслового снаряжения и продовольствия» $[11$, л. 24]. 
Норвежскому гражданину Христенсену, одному из первых заключившему концессионный договор на китобойный промысел в 1923 г. на 15 лет, требования Главного концессионного комитета по «точному исполнению издаваемых законов и правил РСФСР» предъявлены были позже, в январе 1924 года [17, л. 12-13].

Вопрос об иностранной рабочей силе являлся трудноразрешимым для советского Правительства на концессионных предприятиях Северного Сахалина, Камчатки и Приморской области. Задача Правительства «сводилась к тому, чтобы по возможности ограничить концессионера в их праве привлекать рабочую силу из заграницы. Практика концессионных договоров показывает, что политика Правительства в этом отношении с течением времени становится все более жесткой...» [21, л. 43]. Действительно, по концессионным договорам, заключенным в 1925-1927 гг., число иностранных рабочих и служащих постепенно сокращалось. По договорам предусматривалось право концессионеров привлекать административный и высококвалифицированный персонал в числе не более $50 \%$ и рабочих средней и низшей квалификации, а также чернорабочих - не более $25 \%$. Однако на практике наблюдалось иное. Следствием недостаточной советской квалифицированной рабочей силы являлось несоблюдение норм процентного соотношения советских и иностранных рабочих на таких концессионных предприятиях горнодобывающей промышленности, как «Тетюхе», «Кита Карафуто Коогио Кабусики Кайша», «Кита Карафуто Секию Кабусики Кайша» и др. [27, с. 100-104] с преобладанием китайской, японской рабочей силы. Предоставляемые льготы рабочим и служащим, направляемым органами Народного комиссариата труда на постоянную работу в государственные, концессионные предприятия на Камчатском полуострове и острове Сахалин, не решали проблему устранения дефицита квалифицированной советской рабочей силы. Следовательно, повод для взаимных претензий оставался: со стороны советских органов власти к концессионерам - в вопросах найма и соотношения квалифицированной рабочей силы в преимущественном преобладании отечественной, со стороны концессионеров - ее недостатке.
Принимались различные меры для решения этой проблемы. Так, для выполнения условий концессионных договоров и по «соображениям политического характера» концессионерам предоставлялись дополнительные льготы в вопросах тарифов, налогов, отсрочках постройки заводов, передаче в безвозмездное пользование техники и т. д. [10, л. 40]. Также обращение Всесоюзного центрального совета профессиональных союзов к низовым профорганизациях «при предъявлении всякого рода требований к владельцам частных и концессионных предприятий союзы должны воздерживаться от таких требований, которые могут привести к ликвидации предприятия» $[5$, л. 7] на практике последними не нарушалось.

Со второй половины 1930-х гг. в связи с нарастанием военной угрозы со стороны Германии и Японии, усилением международной напряженности меняется внешняя и внутренняя политика Советского Союза. Советское руководство, получая постоянные специальные сообщения из резидентур о возможном нападении Японии на СССР [23, с. 32], стало проводить политику массовой проверки иностранцев. Особое внимание уделили иностранным специалистам, трудившимся в тот период как на важных государственных, так и концессионных предприятиях страны. Меры воздействия к иностранным специалистам были различны. Например, на концессии «Кита Карафуто Коогио Кабусики Кайша» за несчастные случаи на производстве, происходившие с рабочими, японский инженерный состав предприятия (горного инженера Айми Томидзе, штейгера Сугавара Сейици) привлекли к уголовной ответственности и тюремному заключению. Такие меры в отношении японских специалистов способствовали досрочному завершению контрактов и массовому отъезду из СССР на родину не только других инженеров, но и квалифицированных японских рабочих [15, л. 298-298 об.]. Директор вышеуказанной концессии Мураяма в письме начальнику Западно-Сахалинского горного округа Вовченко в сентябре 1937 г. указывал: «...почти все увольняются и уезжают. В связи с этим обстоятельством Общество вынуждено сократить свою работу и производство», а также сократить советских, китайских постоянных рабочих и сезонных грузчиков в со- 


\section{ВЛАСТЬ И ОБЩЕСТВО}

ответствии со статьей 47 пункта «а» Кодекса законов о труде и пунктами 14, 19 действующего коллективного договора предприятия [12, л. 299-300]. При этом въезд на о. Сахалин других японских инженеров не разрешался советскими органами власти [13, л. 301]. Выполнение производственного плана 1937 г. оказалось для концессионного предприятия затруднительным. В 1939 г., как утверждает исследователь Н.В. Марьясова, концессионный договор советского правительства с «Кита Карафуто Коогио Кабусики Кайша» был расторгнут [9, с. 161]. Однако на основании архивных документов удалось выяснить, что на указанной концессии японские рабочие и служащие продолжали трудиться и в начале 1940-х годов. Так, на 1 марта 1943 г. их насчитывалось 80 человек, русских - 99 человек [26, с. 110]. Следует заметить, что, несмотря на ликвидацию практически всех концессионных предприятий в СССР к середине 1930-х гг., на Северном Сахалине и Камчатке продолжали действовать японские концессии «Кита Карафуто Секию Кабусики Кайша» (нефтяная), «Кита Карафуто Коогио Кабусики Кайша» (угольная) и «Ничиро Гиогио Кабусики Кайша» (рыбопромышленная). Они явились фактором сдерживания Японии от военного вторжения на советский Дальний Восток [26, с. 111].

Иностранные граждане - квалифицированные специалисты и рабочие - с середины 1920-х гг. трудоустраивались и на государственные промышленные предприятия СССР, кооперативные и хозяйственные учреждения [7]. Так, в автономную индустриальную колонию «Кузбасс», на рудники Кузнецкого каменноугольного бассейна, в 1926 г. был принят горнорабочий Юнтунен «с оплатой согласно коллективному договору, квартира и прочие коммунальные услуги предоставляются бесплатно» [2, л. 33, 35]. В 1927 г. на Кузбассе работал голландский инженер-архитектор Ван-Логем [1, л. 5], поступали предложения специалистов из Страсбурга (Франция), Канады [4, л. 25, 32]. Специалисты из США, Австрии, Венгрии, Германии и Чехословакии вместе с советскими специалистами организовывали производственную деятельность, передавали им свои знания и опыт на тракторном заводе, заводах «Баррикады» и «Красный
Октябрь» г. Сталинграда. При этом иностранные граждане планировали при первой возможности вернуться на родину, то есть свое пребывание в СССР рассматривали как временное явление [18]. Уже в первой половине 1930-х гг. наблюдается массовое возвращение немецких рабочих в Германию. Однако постоянно проживающих в СССР, например, женщин - немцев Поволжья, советские государственные и общественные организации активно вовлекали в сельскохозяйственный производственный труд трактористами, молотильщицами хлеба и т. п. [22, с. 104].

В конце 1920-х - начале 1930-х гг. большинство концессий переходит в собственность советского государства. Если на 1 октября 1928 г. действовало 110 концессий [24, с. 28], то на 1 августа 1935 г. в СССР насчитывалось 11 действующих иностранных концессионных предприятий (среди них: по одному - датское, шведское, норвежское и французское, три - германских и четыре - японских) [24, с. 107], на 1 января 1937 г. - пять [26, с. 108].

Несмотря на массовое возвращение иностранных граждан на родину в первой половине 1930-х гг., японские рабочие и служащие продолжали трудиться на концессионных предприятиях и в начале 1940-х годов. Например, на 1 января 1943 г. на руднике Дуэ японского концессионного предприятия «Кита Карафуто Коогио Кабусики Кайша» насчитывалось 28 японских служащих и 51 рабочий (соответственно русских - 4 и 95 чел.) [19, л. 312]. При этом численность отечественных рабочих высшей квалификации, представленных крепильщиками, слесарями, плотниками, печниками, машинистами, вагонщиками, была более чем в 1,5 раза больше, чем японских (31 чел. русских и 19 чел. японских) и в 2 раза больше трудилось советских рабочих средней и низшей квалификаций (66 чел. русских и 32 чел. японских) [20, л. 327]. Приведенный фактический материал свидетельствует, что вопросам повышения профессионального уровня советских рабочих, в том числе вопросам процентного преобладания отечественной квалифицированной рабочей силы на концессионных предприятиях, уделялось значительное внимание советскими органами власти, профсоюзами на всем протяжении концессионной практики. 
Результаты. Подводя итоги, мы можем сделать вывод, что сложнейшие задачи восстановления разрушенного национального хозяйства и выхода советской России из политической и экономической изоляции в 1920-е гг. руководство страны пыталось решать с помощью иностранных предпринимателей в форме концессионной помощи. Однако противоречия возникли на начальном этапе привлечения иностранного капитала в советскую экономику. Несмотря на разработанные нормативные документы и требования советского трудового законодательства в вопросах найма, концессионеры не всегда соблюдали основные положения концессионных договоров, допуская преобладание иностранной рабочей силы на своих предприятиях. Основная причина: дефицит квалифицированной советской рабочей силы. Отсюда возникали конфликты, однако они не приводили к закрытию концессионных предприятий.

В первой половине 1940-х гг. на японских концессионных предприятиях численность отечественных рабочих, в том числе рабочих высшей квалификации, превышала численность иностранной рабочей силы, что свидетельствовало об устранении дефицита и достижении необходимых квалификационных навыков советских рабочих в процессе индустриализации страны в 1920-1930-е годы.

Массовое закрытие концессионных предприятий совпало со временем свертывания нэпа, с конца 1920-х гг.; массовый отъезд иностранных специалистов - с начала 1930-х гг., временем ухудшения международной обстановки и их постоянных проверок. Концессионные предприятия завершили свою деятельность в СССР к середине 1940-х годов. Они ликвидировались решением советских органов власти в силу политических соображений, а не несоблюдением концессионерами законодательных требований.

\section{СПИСОК СОКРАЩЕНИЙ}

ИНО ГЭУ - иностранный отдел Главного экономического управления.

Главгортоп - Главное горно-топливное управление.

ОГПУ - Объединенное государственное политическое управление.

\section{СПИСОК ЛИТЕРАТУРЫ}

1. В Главгортоп, 15 февраля 1927 г. // Государственный архив Российской Федерации (ГАРФ).Ф. 3429. - Оп. 3. - Д. 1134. - Л. 5.

2. В ИНОГЭУ ВСНХ СССР, 13 сентября 1926 г. // ГАРФ. - Ф. 3429. - Оп. 3. - Д. 1134. - Л. 33-35.

3. В Концессионный комитет ВСНХ СССР // Российский государственный архив экономики (РГАЭ). - Ф. 1943. - ОП. 22. - Д. 91. - Л. 10.

4. В представительство «Кузбасса», 13 октября 1926 г. // ГАРФ. - Ф. 3429. - Оп. 3. - Д. 1134. Л. 25-32.

5. ВЦСПС о профсоюзной работе на частных и концессионных предприятиях // ГАРФ. - Ф. 8350. Оп. 1. - Д. 327. - Л. 7-8.

6. Декрет СНК РСФСР «Общие экономические и юридические условия концессий» от 23 ноября 1920 г. - Электрон. текстовые дан. - Режим доступа: http://www.consultant.ru/cons/cgi/online.cgi? red (дата обращения: 17.03.2019). - Загл. с экрана.

7. Ерохина, О. В. Организации трудовых иммигрантов Чехословакии на территории Фроловского района Нижне-Волжского края в 1920-1930-е гг. / О. В. Ерохина, Е. Л. Фурман // Вестник Российского университета дружбы народов. Серия: История России. - 2018. - № 17 (4). - С. 890-913.

8. Копия. Концессионный договор // ГАРФ. Ф. 8350. - Оп. 1. - Д. 704. - Л. 15-21.

9. Марьясова, Н. В. Иностранный капитал на Дальнем Востоке России в 20-30-е гг. (концессии и концессионная политика советского государства) / Н. В. Марьясова. - Владивосток : Изд-во Дальневост. ун-та, 2000. -168 с.

10. «Мологолес», 14 июля 1925 г. // Российский государственный архив социально-политической истории (РГАСПИ). - Ф. 76. - Оп. 3. - Д. 317. Л. 38-41.

11. Народному комиссару иностранных дел // РГАЭ. - Ф. 1943. - Оп. 22. - Д. 36. - Л. 24-24 об.

12. Начальнику Западно-Сахалинского горного округа г-ну Вовченко // РГАЭ. - Ф. 8225. - Оп. 1. Д. 5269. - Л. 299-300.

13. Начальнику Западно-Сахалинского горного округа г-ну Вовченко. Копия: Дуйскому рудкому и инспектору труда Западно-Сахалинского горного округа // РГАЭ. - Ф. 8225. - Оп. 1. - Д. 5269. - Л. 301.

14. Основные принципы концессионных договоров // Документы внешней политики СССР. Т. 4. 19 марта - 31 декабря 1921. - М. : Госполитиздат, 1960. -836 c.

15. Переговоры с директором концессионного общества «ККККК» Мураяма, переводчик Озава, состоявшиеся в кабинете начальника горного округа т. Вовченко, 9 сентября 1937 г. // РГАЭ. Ф. 8225. - Оп. 1. - Д. 5269. - Л. 298-298 об. 
16. Постников, С. П. Социокультурный облик промышленных рабочих России в 1900-1941 гг. / С. П. Постников, М. А. Фельдман. - М. : Российская политическая энциклопедия (РОССПЭН), 2009. -367 c.

17. Председателю Главконцесскома тов. Г.Л. Пятакову // РГАЭ. - Ф. 1943. - Оп. 22. - Д. 108. Л. $12-13$.

18. Резаненко, О. О. Условия труда иностранных специалистов и рабочих при реконструкции и строительстве промышленных предприятий Сталинграда в конце 1920-х - 1930-е гг. / О. О. Резаненко // Глобальный научный потенциал. - 2017. № 10 (79). - C. 54-57.

19. Список рабочих и служащих по отделам на 1-е января 1943 г. рудника Дуэ // РГАЭ. - Ф. $8225 .-$ Оп. 1. - Д. 5269. - Л. 312.

20. Список рабочих по квалификациям концессионного общества «ККККК» на 1-е марта 1943 г. // РГАЭ. - Ф. 8225. - Оп. 1. - Д. 5269. - Л. 326-327.

21. Справка по вопросу об иностранной рабочей силе в концессионных предприятиях на Северном Сахалине, Камчатке и Приморской области // ГАРФ. - Ф. 8350. - Оп. 1. - Д. 327. Л. 43-44.

22. Фалалеева, Л. А. «Маленькие винтики огромной государственной машины». Становление и развитие системы ясельных учреждений в 1920 1930-е годы (по материалам Республики немцев Поволжья) / Л. А. Фалалеева // Вестник Волгоградского государственного университета. Серия 4, История. Регионоведение. Международные отношения. - 2017. - Т. 22, № 2. - C. 98-108. - DOI: https:// doi.org/10.15688/jvolsu4.2017.2.10

23. Хаустов, В. Сталин, НКВД и репрессии 1936 1938 гг. / В. Хаустов, Л. Самуэльсон. - М. : Российская политическая энциклопедия (РОССПЭН), 2010. $432 \mathrm{c}$.

24. Хромов, С. С. Иностранные концессии в СССР. Исторический очерк. Документы. Ч. II / С. С. Хромов. - М. : Издат. центр Ин-та российской истории РAH, 2006. $-404 \mathrm{c}$.

25. Циркулярное письмо Объединенного государственного политического управления № 7/37 // РГАСПИ. - Ф. 76. - ОП. 3. - Д. 317. - Л. 41-45.

26. Юдина, Т. В. Концессионная политика и практика на Дальнем Востоке в 1920-1940-е гг.: компромиссы и результаты / Т. В. Юдина // Вестник Волгоградского государственного университета. Серия 4, История. Регионоведение. Международные отношения. - 2016. - Т. 21, № 3. - С. 107-113. DOI: https://doi.org/10.15688/jvolsu4.2016.3.13

27. Юдина, Т. В. Советские рабочие и служащие на концессионных предприятиях СССР в годы нэпа / Т. В. Юдина. - Волгоград : Изд-во ВолГУ, 2009. -444 c.

\section{REFERENCES}

1. V Glavgortop, 15 fevralya $1927 \mathrm{~g}$. [To the Main Mining Administration, February 15, 1927]. Gosudarstvennyy arkhiv Rossiyskoy Federatsii (GARF) [State Archive of the Russian Federation], F. 3429, Op. 3, D. 1134, L. 5.

2. V INO GEU VSNKh SSSR, 13 sentyabrya 1926 g. [To the Foreign Department of the Main Economic Department of the USSR Supreme Council of the National Economy Concession Committee, September 13, 1926]. GARF [State Archive of the Russian Federation], F. 3429, Op. 3, D. 1134, L. 33-35.

3. V Kontsessionnyy komitet VSNKh SSSR [To the USSR Supreme Council of the National Economy Concession Committee]. Rossiyskiy gosudarstvennyy arkhiv ekonomiki (RGAE) [Russian State Archives of Economics], F. 1943, Op. 22, D. 91, L. 10.

4. V predstavitelstvo «Kuzbassa», 13 oktyabrya 1926 g. [To Kuzbass Representatives, October 13, 1926]. GARF [State Archive of the Russian Federation], F. 3429, Op. 3, D. 1134, L. 25-32.

5. VTsSPS o profsoyuznoy rabote na chastnykh i kontsessionnykh predpriyatiyakh [All-Union Central Trade Union Council on Trade-Union Activity at Private and Concessional Enterprises]. GARF [State Archive of the Russian Federation], F. 8350, Op. 1, D. 327, L. 7-8.

6. Dekret SNK RSFSR «Obshchie ekonomicheskie $i$ yuridicheskie usloviya kontsessii» ot 23 noyabrya $1920 \mathrm{~g}$. [Decreet of the Council of People's Commissars of the Russian Soviet Federative Socialist Republic "General Economic and Legal Conditions of Concessions" of November 23, 1920]. URL: http://www.sonsultant.ru/ cons/cgi/online. cgi?red (accessed 17 March 2019).

7. Erokhina O.V., Furman E.L. Organizatsii trudovykh immigrantov Chekhoslovakii na territorii Frolovskogo rayona Nizhne-Volzhskogo kraya v 19201930-e gg. [Organizations of Czechoslovakian Labor Immigrants in Frolovo Municipality of Low Volga Border in the 1920s - 1930s]. Vestnik Rossiyskogo universiteta druzhby narodov. Seriya: Istoriya Rossii [RUDN Journal of Russian History], 2018, no. 17 (4), pp. 890-913.

8. Kopiya. Kontsessionnyy dogovor [Copy: Concession Contract]. Gosudarstvennyy arkhiv Rossiyskoy Federatsii [State Archive of the Russian Federation], F. 8350, Op. 1, D. 704, L. 15-21.

9. Maryasova N.V. Inostrannyy kapital na Dalnem Vostoke Rossii v 20-30-e gg. (kontsessii $i$ kontsessionnaya politika sovetskogo gosudarstva) [Foreign Capital in the Far East Russia in the 20s - 30s (Concessions and Concession Policy of the Soviet State)].Vladivostok, Izd-vo Dalnevostochnogo universiteta, 2000. $168 \mathrm{p}$.

10. «Mologoles», 14 iyulia 1925 g. ['Mologoles', July 14, 1925]. Rossiyskiy gosudarstvennyy arkhiv sotsialno-politicheskoy istorii (RGASPI) [Russian 
State Archive of Social and Political History], F. 76, Op. 3, D. 317, L. 38-41.

11. Narodnomu komissaru inostrannykh del [To the People's Commissar of Foreign Affairs]. RGAE [Russian State Archive of Economics], F. 1943, Op. 22, D. 36, L. 24-24 ob.

12. Nachalniku Zapadno-Sakhalinskogo gornogo okruga g-nu Vovchenko [To Mr. Vovchenko, the Chief of West-Sakhalin Mounatain District]. $R G A E$ [Russian State Archive of Economics], F. 8225, Op. 1, D. 5269, L. 299-300.

13. Nachalniku Zapadno-Sakhalinskogo gornogo okruga g-nu Vovchenko. Kopiya: Duyskomu rudkomu i inspektoru truda Zapadno-Sakhalinskogo gornogo okruga [To Mr. Vovchenko, the Chief of West-Sakhalin Mountain District. Copy: To the Duy Mining Committee of WestSakhalin Mountain District]. RGAE [Russian StateArchive ofEconomics], F. 8225, Op. 1, D. 5269, L. 301.

14. Osnovnye printsipy kontsessionnykh dogovorov [The Main Foundations of Concession Contracts]. Dokumenty vneshney politiki SSSR. T. 4. 19 marta - 31 dekabrya 1921 [Soviet Foreign Policy Documents, vol. 4, March 19 - December 31, 1921]. Moscow, Gospolitizdat, 1960. 836 p.

15. Peregovory s direktorom kontsessionnogo obshchestva «KKKKK» Murayama, perevodchik Ozava, sostoyavshiesya v kabinete nachalnika gornogo okruga t. Vovchenko, 9 sentyabrya $1937 \mathrm{~g}$. [Negotiations with Head of the Concession Community 'KKKKK' Murayama, Translator Ozava, at the Office of Chief of Mountain District Vovchenko]. RGAE [Russian State Archive of Economics], F. 8225, Op. 1, D. 5269, L. 298-298 ob.

16. Postnikov S.P., Feldman M.A. Sotsiokulturnyy oblik promyshlennykh rabochikh Rossii v 1900$1941 \mathrm{gg}$. [Sociocultural Image of Russian Manufacture Employees in 1900- 1941]. Moscow, Rossiyskaya politicheskaya entsiklopediya (ROSSPEN), 2009.367 p.

17. Predsedatelyu Glavkontsesskoma tov. G.L. Pyatakovu [To Pyatakov G.L., the Chairman of the Main Concession Commitee]. RGAE [Russian State Archive of Economics], F. 1943, Op. 22, D. 108, L. 12-13.

18. Rezanenko O.O. Usloviya truda inostrannykh spetsialistov i rabochikh pri rekonstruktsii i stroitelstve promyshlennykh predpriyatiy Stalingrada v kontse 1920-kh - 1930-e gg. [Labor Conditions of Foreign Experts and Employees During Reconstruction and Building of Manufacturing Enterprises in Stalingrad in the Late 1920s - 1930s]. Globalnyy nauchnyy potentsial [Global Scientific Potential], 2017, no. 10 (79), pp. 54-57.

19. Spisok rabochikh i sluzhashchikh po otdelam na 1-e yanvarya $1943 \mathrm{~g}$. rudnika Due [The List of Workers and Employees in Departments of Dui Minerybas of January 1, 1943]. RGAE [Russian State Archive of Economics], F. 8225, Op. 1, D. 5269, L. 312.
20. Spisok rabochikh po kvalifikatsiyam kontsessionnogo obshchestva «KKKKK» na 1-oe marta 1943 g. [The List of Workers by Qualifications of Concession Society 'KKKKK' as of March 1, 1943]. RGAE [Russian State Archive of Economics], F. 8225, Op. 1, D. 5269, L. 326-327.

21. Spravka po voprosu ob inostrannoy rabochey sile v kontsessionnykh predpriyatiyakh na Severnom Sakhaline, Kamchatke i Primorskoy oblasti [Official Document on Labor Force at Concession Enterprises in North Sakhalin, Kamchatka and Primorsky Region]. GARF [State Archive of the Russian Federation], F. 8350, Op. 1, D. 327, L. 43-44.

22. Falaleeva L.A. «Malenkie vintiki ogromnoy gosudarstvennoy mashiny». Stanovlenie i razvitie sistemy yaselnykh uchrezhdeniy v 1920-1930-e gody (po materialam Respubliki Nemtsev Povolzhya) ["Small Cogs of a Huge State Machine." Formation and Development of the Nursery System in the 1920s 1930s (Based on Materials from the Volga Germans Republic)]. Vestnik Volgogradskogo gosudarstvennogo universiteta. Seriya 4, Istoriya. Regionovedenie. Mezhdunarodnye otnosheniya [Science Journal of Volgograd State University. History. Area Studies. International Relations], 2017, vol. 22, no. 2, pp. 98108. DOI: https://doi.org/10.15688/jvolsu4.2017.2.10

23. Khaustov V., Samuelson L. Stalin, NKVD $i$ repressii 1936-1938 gg. [Stalin, People's Commissariat for Internal Affairs and Repressions in 1936-1938]. Moscow, Rossiyskaya politicheskaya entsiklopediya (ROSSPEN), 2010.432 p.

24. Khromov S.S. Inostrannye kontsessii v SSSR. Istoricheskiy ocherk. Dokumenty. Ch. II [Foreign Concessions in the USSR. Historical Essay. Documents. Part 2]. Moscow, Izdat. tsentr In-ta rossiyskoy istorii RAN, 2006. 404 p.

25. Tsirkulyarnoe pismo Obyedinennogo gosudarstvennogo politicheskogo upravleniya № 7/37 [Circular Letter of All-Union State Political Administration no. 7/37]. RGASPI [Russian State Archive of Social and Political History], F. 76, Op. 3, D. 317, L. 41-45.

26. Yudina T.V. Kontsessionnaya politika i praktika na Dalnem Vostoke v 1920-1940-e gg.: kompromissy i rezultaty [Concession Policy and Practice at the Russian Far East in 1920-1940s: Trade-Offs and Results]. Vestnik Volgogradskogo gosudarstvennogo universiteta. Seriya 4, Istoriya. Regionovedenie. Mezhdunarodnye otnosheniya [Science Journal of Volgograd State University. History. Area Studies. International Relations], 2016, vol. 21, no. 3,pp. 107-113. DOI: https:// doi.org/10.15688/jvolsu4.2016.3.13

27. Yudina T.V. Sovetskie rabochie i sluzhashchie na kontsessionnykh predpriyatiyakh SSSR v gody nepa [Soviet Workers and Employees on the USSR Concession Enterprises in NEPYears]. Volgograd,Izd-vo GolGU,2009.444p. 


\section{Information about the Author}

Taisiya V. Yudina, Doctor of Sciences (History), Professor, Department of Russian and World History, Archaeology, Volgograd State University, Prosp. Universitetsky, 100, 400062 Volgograd, Russian Federation, taisia.yudina@volsu.ru, https://orcid.org/0000-0003-0526-6484

\section{Информация об авторе}

Таисия Васильевна Юдина, доктор исторических наук, профессор кафедры отечественной и всеобщей истории, археологии, Волгоградский государственный университет, просп. Университетский, 100, 400062 г. Волгоград, Российская Федерация, taisia.yudina@volsu.ru, https://orcid.org/0000-0003-0526-6484 